\title{
Investigating the concept of despair and its relation with sin in Kierkegaard's view
}

\author{
Mina Tabatabaee \\ A faculty member, department of Philosophy, Islamic Azad University, Meymeh branch, Isfahan, IRAN \\ Mptabaei@yahoo.com
}

\begin{abstract}
This paper attempts to explain the Kierkegaard's view concerning despair and its relation with sin. This paper is based on the book "Sickness unto death" by Kierkegaard which is in his opinion beside the book "Fear and trembling" is the most important of his works wherein a full explanation of human despair is provided. To explain despair, it is necessary for the root cause and origin of this despair to be first addressed that in the Kierkegaard, it is the very personal alienation and his absorption in the society. For this purpose, first an explanation of this origin and the main role the self assumes in this regard are addressed. Later, despair arising from a bidirectional relation of the self is dealt with and then the greatest sin which is despair is investigated.
\end{abstract}

Keywords: Individual, Self, Despair, Sin, God, Sickness unto death.

\section{Introduction}

A close study of the book" Sickness unto death" and comparing it with other related works illustrates the significance of the concepts of sin and despair in the Kierkegaard's thinking as key concepts. These two concepts are closely related and most concepts Kierkegaard has applied in his own writings such as individual, self, impossible and synthesis are influenced by these two concepts and hence they are understood in the light of realization of these two concepts and their roles in the Kierkegaard's writings. In addition, recognition and illustration of the significance of these two concepts in the Kierkegaard's thinking could be a solution to differences and ambiguities that exist among the Kierkegaard's researchers, particularly in relation with the connection of parts one and two of the book "Sickness unto death" and his conception of revelation. In this paper, attempts are made to explain these two concepts in the thinking of Kierkegaard and to describe the relation of these two with each other. For this, it is necessary to deal with the concept of individual and its significance for Kierkegaard. 


\section{Individual:}

Kierkegaard is known as the father of the Existential philosophy, a philosophy which stresses more than anything else on oneself and individuation of man. Kierkegaard states any individual is responsible for giving sense to his life and should live it enthusiastically and authentically. It can be said that this view of Kierkegaard, forming the foundation of his philosophy has been raised largely in contradiction with the Hegelian views and the impact they left on the public thinking; a view that considers individual as secondary to the whole and subject to the whole. In Hegel's view, the individual potentiates his own identity by way of another. He, by eliminating the boundary between the individual and others forms an integrated individuation wherein the personal individuation cannot be discerned.

On the book" Sickness unto death ", Lewis Duperet writes: "The despair Kierkegaard mentions is mostly related to a lackadaisical and wavering attitude of a mass society; a society that has replaced the individual responsibility with historical awareness. When social functions replace authentic self, the mass, by lack of accountability peculiar to itself and refusal to commitment will be transformed into "actuality". Christianity under such circumstances where the individual has gone away from his self is in danger more than the past, because Christianity has become a concrete system consisting of opinions and instructions that no longer have impacts on the individual's life. Thus, the Kierkegaard's writings could be regarded as an attempt for correcting wrong attitudes towards Christianity at his time; an attempt that seeks to get the followers of Christianity acquainted with necessity and importance of the individual's being (Deede, 2003). Under such circumstance, the relation of man is severed with his self and with God and Kierkegaard in the book" Sickness unto death" seeks to link once again individual with these two. On this path, Kierkegaard makes use of the concept of self. Self appears in the Kierkegaard's writing as a factor that relates itself with itself and recovers the lost individuation in the society. It is through the appearance of self we become familiar with despair and sin man is faced with.

\section{Self:}

The possibility of despair depends on "self" as a relation. Defining self in in the book" Sickness unto death" Kierkegaard states:

Self is a relation which relates itself to its own self, or it is that in the relation [which accounts for it] that the relation relates itself to its own self; the self is not the relation but [consists in the fact] that the relation relates itself to its own self. Man is a synthesis of the infinite and the finite, of the temporal and the eternal, of freedom and necessity; in short it is a synthesis. A synthesis is a relation between two [factors]. So regarded, man is not yet a self..... . If on the contrary the relation relates itself to its own self, the relation is then the positive third term, and this is the self ( Kierkegaard, 1980).

Here, Kierkegaard admits the human self is like a connector that connects the two sides of the relation and hence, there is a third term which is other than the two components of the synthesis.

Such a relation which relates itself to its own self (that is to say, a self) must either have constituted itself or have been constituted by another. 
This relation could not have been constituted by itself, because in this case a cycle will arise and is vicious. If a relation relating itself with its own self is constituted by "another", hence in fact, the relation is the third term, but this relation being the third term is again a relation that relates itself with something that has constituted the whole relation.

The human self is such a derived, constituted relation, a relation who relates itself to its own self, and in relating itself to its own self relates itself to another.

It is understood from this statement that since self is the connector of itself with its own self, constituted by another, hence by way of it itself will be made related with another; consequently, the self forms two relations, one is the relation of itself with its own self and the relation of itself with another.

In Kierkegaard opinion, another which is constituted the whole relation is God. From this perspective, two factors are necessary for the constitution of the self. On one hand, the self is constituted by relying on God and on the other hand, the self is constituted by willing to be one's own self (Deede, 2003).

\section{Despair:}

One of the main concepts for Kierkegaard is despair which is a modified version of anxiety. For him, these two potentiate the Self dialectic and both are discerned by referring to the concept of sin. The bidirectional relation of self marks two types of despair: "willing to be one's own self" and " not willing to be one's own self". The first type of despair is linked with self as the connector of itself with its own self, while its second type relies on self as the connector of itself with God (Theunissen, 2007). The second type of despair relies on the point that the human self is a derived and constituted relation that should relate itself with that which it is derived from and constituted by it. Self only can relate itself with its own self by means of its relation with that which has constituted the whole relation (Kierkegaard, 1980).

Kierkegaard defines despair as follows:

Despair is the disrelationship in a relation which relates itself to itself.

But the synthesis is not the disrelationship; it is merely the possibility, or, in the synthesis is latent the possibility of the disrelationship.

Here, we observe a fundamental role that synthesis plays in defining self by Kierkegaard. One of the Kierkegaard's researcher's states: It has been generally determined that defining man as synthesis is the fundamental point in Kierkegaard's anthropology. The human being is a synthesis in two different meanings. The first meaning refers to the fact that the human being is potentiated of various parts while the second meaning includes the need for determining and establishing a synthesis between these parts in order to prevent the disrelationship leading to despair.

On despair, Kierkegaard "by viewing the synthesis potentiating factors" writes:

"The self is the conscious synthesis of infinitude and finitude which relates itself to itself, whose task is to become itself, a task which can be performed only by means of a relationship to God. 
We in the book "Sickness unto death" observe other self syntheses: the synthesis of possible factor and necessary factor, synthesis of temporal factor and eternal factor. Finitude and being temporal display limited human aspects while finitude and necessary and eternal are aspects that man can imagine and hopes to attain them.

"God and man are two qualities separated by means of an infinite qualitative difference".

In his writings, Kierkegaard insistently stresses on this qualitative difference between God and man. On the other hand, Kierkegaard in his definition of self, while stressing on the impossibility of attaining to oneself without the relation of oneself with God states the individual cannot merely by means of his oneself relates himself with God. This is the foundation of despair that Kierkegaard has defined it as defiance. In this despair, man has a will to be oneself. He is aware of certain infinitude, but separates "self" from any relation with a power constituting it. Helped with this infinite form, self in despair can be master of it or creates itself. While using this eternal factor wrongly, it has been postulated that self is beyond finitude and being temporal, but in seeking to attain its own synthesis and in rejecting divine help for whom everything is possible, the constitution of this synthesis is impossible (Deede, 2003).

Sin:

Sin for Kierkegaard is " an eternality gone away from an eternal factor: and as a result, al the human suffering is because of being earthly (being temporal). A really main point in the human suffering Kierkegaard always intends to remind his readership is the point that the individual can by creating a balance in his own self attains some inward eternality and consequently, regains some lost repose and tranquility (Khan, 1975). It was previously mentioned that "there is a possibility for latent disrelationship in the synthesis". This disrelationship can be found deeply in sin, which is in fact the main factor of the infinite qualitative difference between God and man. Sin brings about the possibility for the disrelationship that root in despair. In the beginning of the second part "Sickness unto death, Kierkegaard while talking on sin writes down:

Sin is in despair before God to not willing to be oneself, or in despair at willing to be oneself. Thus, $\sin$ is potentiated weakness or potentiated defiance: $\sin$ is the potentiation of despair. The point upon which the emphasis rests is before God, or the fact that the conception of God is involved; the factor which dialectically, ethically, religiously, makes "qualified "despair (to use a juridical term) synonymous with sin is the conception of God.

Sin is related with the despair of disrelationship; disrelationship between man and God. In other words, this is the problem of will, sin takes root in will and hence, Kierkegaard defines two types of despair by a rhetoric of will. Sin is among the things that chokes human throat and in Pascal words it is of those things that takes us to a light which is not the light of wisdom and philosophy. No acquisition science can explain sin because sin is an Existential factor (Mosta'an, 2007). Sin exhorts man and shows the absolute other. So regarded we feel ourselves before God. Therefore, we need to transcend the stage of conscience so to reach the category of being before God. To feel sinful is to feel before God (Verno \& Vale, 1993; Trans by Mahdavi, 1993).

As stated, Kierkegaard directed his attention to an "inverse dialectic" of Christianity by which we make "diplopia" so as to look in the worldly things their spiritual conflicts. For instance, we therefore can discern hope in despair, power in inability and victory in misfortune and 
misery. An inverse dialectic requires us to manifest our thoughts in our actions and this is the thing that places "us in front of ourselves". The Kierkegaard's rhetoric play with the Christianity dialectic was not aimed to make the word of God as to make easily simulations or close to man; rather he attempted to illustrate an absolute distance that separates the human beings from God more as transparently as possible. This pointed out that man for attain felicity thoroughly relies on God's kindness. However, most scholars maintain that "sin" is the absolute distancing factor of human beings from God and as a result, they call Kierkegaard is considered to be a radical Christian who prescribes some extreme piety. Another more justifiable explanation is that it is the forgiveness capacity of the God's unforgivable factor that creates this absolute distance. Our struggle for the God's forgiveness to be accepted gets in stuck in the abyss of despair, even it involves a second order despair that we are faced with some evil despair in addition to the fact we consider forgiveness as impossible by which we reject with protest any sort of forgiveness. On the other hand, faith in the divine forgiveness could manifest in the cheerfulness and felicity resulting from the fact that everything is possible for God and this results in the fact that we find ourselves from a "newly born" to selves with "eternal credit".

For a Christian faith miracle to happen, it is vital to accept we are in constant mistake about God. In other words, we should discover we are overwhelmed with sin. Understanding this is a condition for faith that should be granted on us by God. The idea of sin cannot be inferred from the mere human origins; rather this idea should be introduced by a transcendental source to this world. The fact we discover we are sinful; we become aware there is a being in front of us against whom we are always mistaken. Accordingly,. We can have faith upon which we can attract God satisfaction. Such satisfaction attraction requires faith so that we believe for God the impossible is possible, and an unforgivable will turn forgivable, If we accept God's forgiveness and bounty quite purely, inwardly and with appreciation, then we have opened a happily aspect of a new beginning toward ourselves. The only thing that hinders this happiness is our rejection or resistance against accepting God's forgiveness. Though God could forgive an unforgivable thing cannot coerce someone to accept this. Therefore, for Kierkegaard "it is only a guilt God cannot forgive and that's not willing to believe in His magnanimity (despair)".

\section{Conclusion}

We infer from the above-mentioned material that an individual alienated from his self and absorbed in the society is faced with despair which in Kierkegaard's view is the greatest sin. Man, to recover his relation with oneself and God requires discerning this despair and struggles to remove it. In this regard, that which is needed is faith. Faith in a God for whom any impossible turns possible. It is only through this sin (despair) that man can recognize the infinite qualitative difference between himself and God and can recognize the only being that can constitute the impossible is no one but God for who every impossible is possible. For Kierkegaard, it is only before God the human self can be the thing it should be, relation that relates itself with its own self, and during its relation of itself to its own self relates itself with another, but to attain this we need faith before God. 


\section{References}

[1] Mosta'an, M. (2007). Kierkegaard: a pious thinker, Tehran: Porsesh Publication.

[2] Vernon, R., \& Vale, J. (1993). phenomenology and philosophies of being. Translated by Yahya Mahdavi. Tehran: Kharazmi Publication.

[3] Deede, K. K. (2003). The Infinite Qualitative difference: Sin, the self, and Revelation in the thought of Soren Kierkegaard, in Journal for Philosophy of Religion. http:// Plato. Stanford. Edu. Entries. Kierkegaard.

[4] Khan, I. (1975). , Kierkegaard's conception on of Evil. Journal of Religion and Health.

[5] Kierkegaard, S. (1980). The Sickness Unto Death, trans, Howard V. Hong and Edna H. Hong. Princeton university.

[6] Theunissen, M. (2007). Kierkegaard's concept of Despair. 